\title{
Teacher Recruitment by County Government and Its Influence on Implementation of Early Childhood Education Curriculum: The Case of Homabay County, Kenya
}

\author{
Edward Otieno Obuya ${ }^{1}$ \\ Ephantus Kaugi ${ }^{2}$ \\ Hellen Guantai ${ }^{3}$ \\ 1. Doctorate Student at the Department of Educational Management, Policy and Curriculum Studies, School of \\ Education, Kenyatta University, Kenya \\ $2 \& 3$ : Supervisors of the Doctorate Student at the Department of Educational Management, Policy and \\ Curriculum Studies, School of Education, Kenyatta University, Kenya
}

\begin{abstract}
The thrust of this study was to assess the influence of teacher recruitment on the implementation of pre-school curriculum. The study employed explanatory sequential mixed methods design. From a target population, 236 head teachers, 313 ECDE teachers and 56 County ECDE officers were randomly sampled yielding 588 participants. Data was collected using questionnaire and interview schedules. Quantitative data for the first phase were analyzed with the assistance of Statistical Package for Social Sciences (SPSS) to generate descriptive and inferential statistic Qualitative data during the second phase were analyzed thematically. Mixed results were obtained indicating that head teachers and ECDE teachers held contrary views regarding teacher's recruitment and deployment. While the head teachers' results indicated that there was a significant and positive correlation $(p=.001,<.05)$, the ECDE teachers revealed a non-statistically correlation $(p=.456,>.05)$, between the recruitment of teachers and curriculum implementation. The conclusion reached was that there was inadequate teacher recruitment and the understaffing was negatively influencing curriculum implementation. It was recommended that national and county government should put in placed a harmonized teacher recruitment policy and employ adequate teachers to effectively implement the curriculum.
\end{abstract}

Keywords: Recruitment, Head teachers, Pre-school teachers, Curriculum implementation.

DOI: $10.7176 /$ RHSS/12-4-04

Publication date: February $28^{\text {th }} 2022$

\section{INTRODUCTION}

Background to the study

This study finds motivation from the promise made by the Sustainable Development Goal -4 that countries must ensure that by 2030, all boys and girls access quality early childhood development care and pre-primary education so that they are ready for primary education (United Nations,2016)

Quality education is determined by a combination of enablers such as the effectiveness of learning, the extent to which their education translates into a range of personal, social and developmental advantages. The quality imparted vary per institutional level depending on the internal school characteristics, such as, relevant aims and goals, good use of time and available support materials which are deployed equitably within a school environment that is supportive to learning (UNESCO,2015). In the same breath, UNESCO (2019) further emphasizes that the appropriate skill acquisition is embodied in the required resources for quality teaching and learning to take place. The implication is that there is the need to go beyond the comfort of improving access and realize that learning is not just about quantitative gains in terms of number of children in the classroom, but also about quality. It is instructive to note that according to UNESCO (2019), the world is off track as far as the delivery its educational commitment by 2030 is concerned. Evidently, there is inadequate trained teachers, infrastructural facilities and disparity in enrollment in the rural and urban areas and in poor and middle income countries.

On the Kenyan front, a study by World Bank (2019) reveals that students in Kenya can only reach 52 percent of their potentiality at 18 years of age, blaming the prevailing circumstances on the quality of educational resources and time for student's engagement in the learning process. This entire process of ensuring equitable and quality education is realized is vested on the docket of a teacher. Invariably, to ensure provision of quality education, a teacher, also referred to as a curriculum implementer, is the determinant of an effective and efficient curriculum implementation at all levels of education. The process of curriculum implementation entails classroom activities that the teacher undertakes to monitor students' progress and evaluate the performance. Teachers are therefore responsible for curriculum implementation. Shimala \& Kamau (2016) opined that learning is influenced by teachers, as they are the ones who execute the dissemination of the structured set of learning experiences, the provision of resources to effectively execute the curriculum plan, and the actual 
execution in the classroom where teacher-learner interactions takes place (Mkpa \& Izuagba,2009). This demonstrates the pivotal role played by teachers in the process of curriculum implementation. To reiterate, teachers are unquestionably the most important human resources in curriculum implementation as they play important role in adopting and implementing the ideas and aspirations of the curriculum designers (Kenya Institute of Curriculum Development,2018). This points to the fact that success of the curriculum relies entirely on teachers. Therefore, appropriate recruitment of trained teachers is a primary factor to consider as it influences curriculum implementation. Arguably, teachers are considered the most crucial factor in the process of curriculum implementation as they contribute to expertise, knowledge and experience in classroom teaching.(Kasau,et.al.,2016).

The impact of staffing and teacher pupil's ratio is very important in determining the level at which teachers implement curriculum. Kasau et al. ,2016 states that recruiting adequate number of teachers ensures a reduction of class size. Consequently, smaller size allows adequate teacher-student interactions which permit teachers to engage individual learner leading to improved curriculum implementation and learning outcome. Research carried out in five Franco Saharan African countries (Burkina Faso, Cameroon, Cote d'Ivoure, Senegal and Madagascar) by Kasau (2016) posit that congested classrooms lead to high teacher workload hence impedes curriculum implementation process and poor-quality learning outcome. Teacher interactions that foster positive classroom environment are important as they make the learners feel cared for and connected with the teacher and learning process (Martin,et.al.,2016).

In the Kenyan contex the Constitution which was promulgated in 2010 created a devolved governance system involving one national and all the county governments aimed at promoting social and economic development. In its fourth schedule, the Constitution stipulates functions and powers of the two levels of government. The schedule particularly gives county governments the responsibility to provide pre-primary education and childcare services (UNESCO, 2012).

The Basic Education Act No 14 of 2013 further affirms that the county government is responsible for the management of ECDE programs including teacher management (Shinali \& Kamau, 2016; Republic of Kenya, 2013). Accordingly, county governments' working is guided by the National ECDE Policy Framework that seeks to ensure that holistic needs of the young children are met (Republic of Kenya, 2006). Devolution of ECDE including teacher recruitment by the county government was perceived as an avenue to address the challenges that bedeviled the sector (Shinali \& Kamau, 2016). Key functions of the county government in the management of ECDE sector include teacher recruitment and deployment of teachers (Republic of Kenya, 2010, 2013). However, empirical studies carried out on ECDE teacher recruitment, have found out that there is significant correlation between teacher recruitment and curriculum implementation (UNESCO, 2012). Despite these efforts by both the national and county governments, there exists an evidence gap regarding the not only the status of teacher recruitment but also its effects on curriculum implementation at the Early Childhood Development and Education in HomaBay County.

\section{Statement of the problem}

The constitution of Kenya 2010 recognizes the central role played by Early Childhood Education Development programmes in the development of children later years of education including teacher recruitment by the county government. Despite its pivotal role played by the Government of Kenya in laying educational foundation, Early Childhood Education in country continues to face a myriad of challenges including teacher recruitment. Although the policies are very clear about teacher recruitment, understaffing of ECDE teachers has threatened every gain that has been made towards improving the quality of early childhood education in the country (Oliech, Ajowi \& Raburu,2018). Robust literature review reveals that teachers continue to face various management challenges including teacher recruitment. In addition, there is lack of adequate empirical evidence to examine the influence of teacher recruitment by the county governments on the implementation of early childhood education curriculum in the Kenya's context. It was on this background that this study critically examined teacher recruitment by the county government and its influence on the implementation of Early Childhood Development and Education Curriculum with reference to Homa- Bay County in Kenya.

\section{Objectives of the study}

To investigate the influence of teacher recruitment by the county government on the implementation of early childhood education curriculum in Homa-Bay County.

\section{Hypothesis of the study}

Ho1- There is no statistically significant influence of teacher recruitment on the implementation of early childhood education curriculum in Homa-Bay county 
Significance of the study.

The study's findings are hoped to be of use by county governments especially the Department of Early Childhood Education where they might provide insights into the issues concerning teachers' recruitment and how it influences on the implementation of curriculum. Therefore, the findings are significant and relevant to the inspectorate and may facilitate making informed decisions by the Chief Education Officer in as far as recruitment of teachers is concerned and aid in addressing understaffing. The study findings may also not only add to the knowledge base and as such, it may form a basis upon which other related studies may be anchored. The study may also serve as a point of reference in as far as future recruitment plans by county governments are concerned.

\section{Theoretical framework}

This particular study was anchored on "Structural Functionalism Theory 1858-1971" which was espoused by Emile Durkheim. The theory proposes that a human society is like an organism and is made up of structures called social institutions. These institutions are specifically structured so that they perform different functions on behalf of the society, each of which has particular consequences in shaping the society.

According to this theory an institution only exists because it serves a vital role in the functioning of the society. This theory is applicable in this study because it explains how the human society is organized and what each of the various social institutions does in order for the society to continue existing. In this study, the county government is one of the various institutions of the society. It serves important roles for the functioning of the entire country.

\section{Conceptual framework}

The conceptual framework in Figure 1 displays a relationship between Independent Variable (IV) and Dependent Variable (DV).

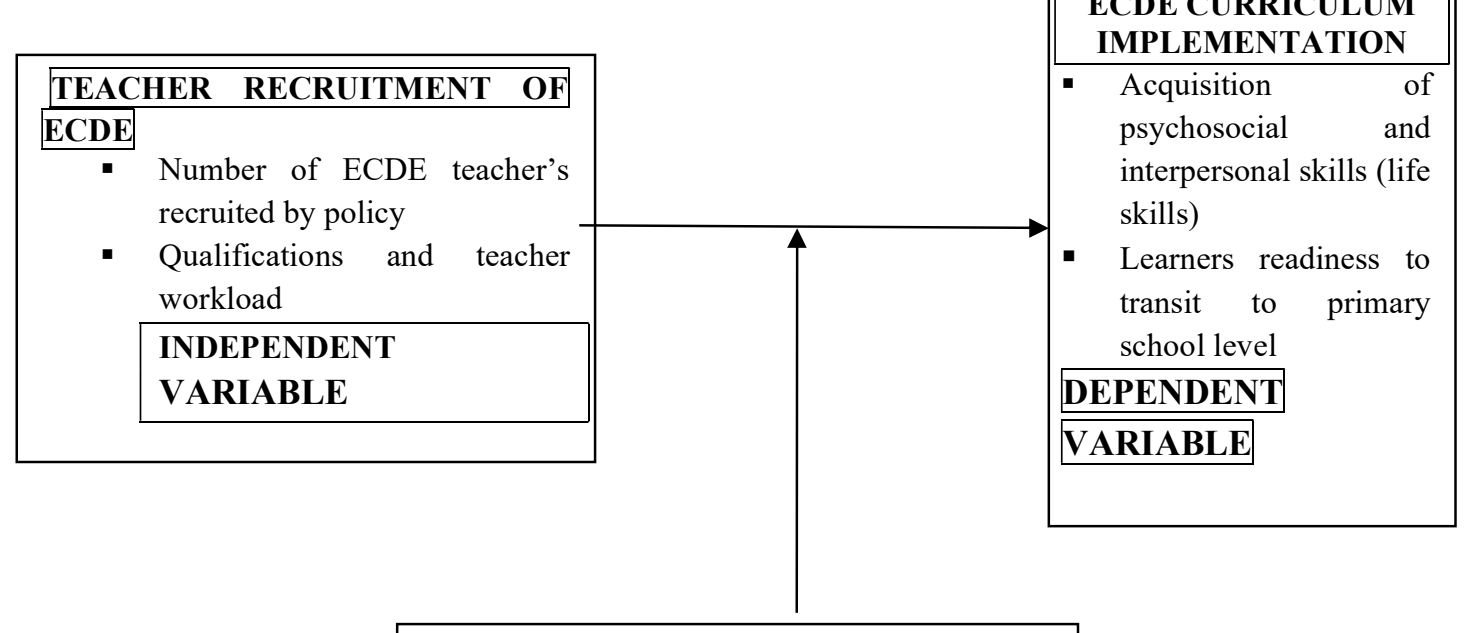

- Geographical location of ECDE

- Commitments of the recruited ECDE teachers

INTERVENING VARIABLE

Figure 1: The conceptual Framework illustrating relationship between recruitment and implementation of ECDE teachers

Source: Modified from Orodho, 2017

Adapting the Structural Functionalism model, this conceptual framework relates the interaction between teacher recruitment (IV) and curriculum implementation(DV). The independent variable for the study comprises the number of ECDE teachers recruited by the county government policy which include; policies on ECDE teacher recruitment, advertisements and qualifications for recruitment as well as quality of recruited teachers in terms of academic and professional qualification. When the policies are well adhered to, quality teachers will be recruited and the quality of curriculum implementation measured in terms of ability for to acquire requisite psychosocial skills and readiness to seamlessly transit to primary school level will be 
achieved. These end results include; acquisition of psychosocial and interpersonal skills.

\section{Research methodology}

The study employed an explanatory sequential design which is one of the variants of mixed method as illustrated in Figure 2. This was in accordance with Creswell, (2018) who posited that the design enables the researchers to follow a logical sequence while handling the research process to the end.

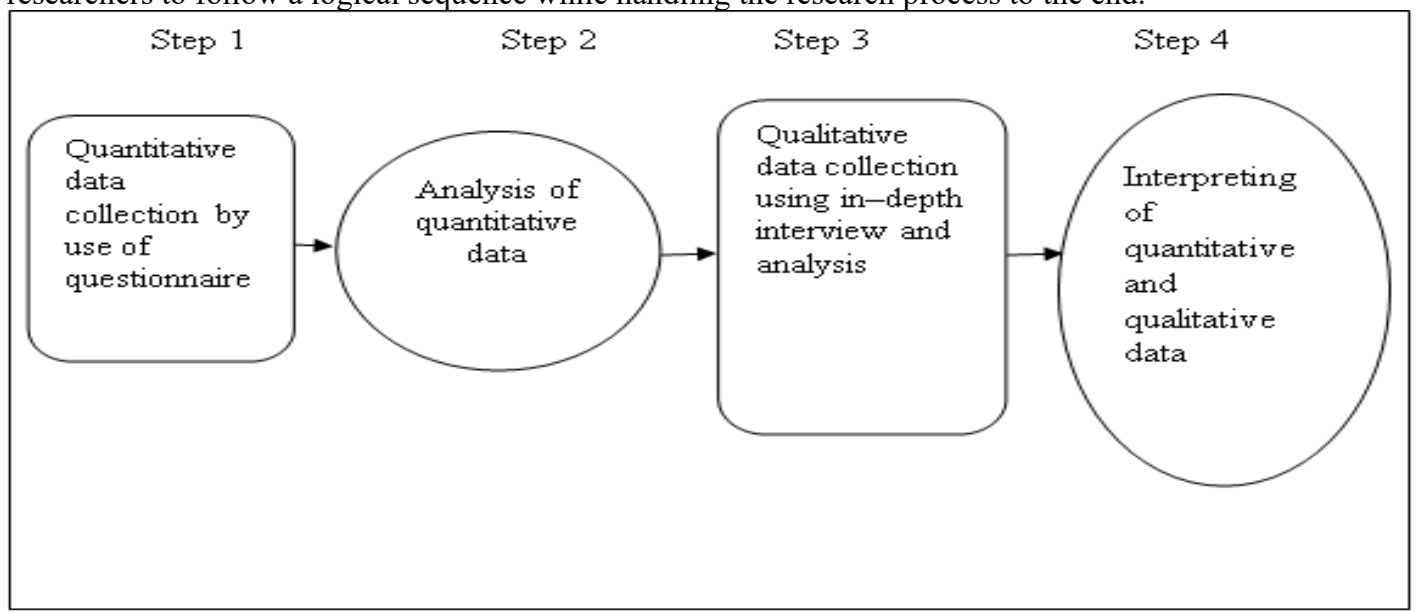

Figure 2 : An illustrative process of the Explanatory sequential mixed methods design

Source: Creswell, 2018

The mixed method design in this study was deemed appropriate since the researcher's intention was to incorporate both quantitative and qualitative methods so as to achieve research objectives. The method also upheld the strengths of quantitative and qualitative approaches and offset their weakness as well.

In line with the explanatory sequential design stages, the quantitative data were collected using questionnaires from the entire sample during the first phase, followed by the qualitative data collection in the second phase to explain the findings in phase 1. . Therefore, phase two of the study subjected selected participants to an intensive interview session. This enabled the researcher to obtain an in-depth inquiry from the participants and gain further insight into the variables under study (Orodho,2017). The use of data merging and triangulation approach were appropriate for this study because the researcher' intention was to understand how teacher recruitment influence curriculum implementation process. (Creswell, 2018).

\section{Location and Sample selection}

The study was conducted in Homa-Bay County in Kenya. The County is found in the former Nyanza Province and lies between latitude 0.30 South and longitude of 34.9 East with a population of 1.131,950 covering 3183.3 square $\mathrm{km}$ with an annual population growth rate of 1.6\% (Kenya National Bureau of Statistics Census Results 2019 in Kenya).

The target population for the study comprised eight hundred and seventy-seven (877) public pre-schools in the eight sub-counties in Homa Bay County, Kenya. the county according to the data available at the Homa Bay County Director of ECDE office. The pre-schools were categorized into urban and rural pre-schools for the sake of easy comparison. Eighty-six (86) pre-schools are found in urban centres within Homa Bay County whereas Seven hundred and ninety-one (791) pre-schools are within the rural areas respectively

A sample was drawn from the target population located in 877 pre-school centers comprising 2245 teachers in Homa-Bay County. (County Government Education Department, 2019; Creswell, 2008). From the target population, 236 head teachers, 313 ECDE teachers and 56 County ECDE officers were sampled yielding a sample size of 588 participants.

\section{Research instruments}

The two main data collection instruments employed were questionnaires and interview schedules as was suggested by Hinds (2011). . Questionnaires were appropriate for data collection because the study was descriptive in nature and questionnaires were found to be suitable data collection instruments for descriptive studies (Kothari, 2004; McNabb, 2004; Mugenda \& Mugenda, 2003; Kothari,2004; Orodho, 2009). Two questionnaires were developed, one for the head teachers and another one for ECDE teachers. Construction of the questionnaires was done systematically according to the research objectives to answer all the research questions by the respondents. Respondents were requested to answer each questionnaire item with assurance of confidentiality so as to provide truthful information with errors being minimized. In order to obtain the required 
data, a variables matrix showing the research instrument and the relevant study variables was developed. These instruments were piloted in the same county, but schools participating in the pilot not included in the main study. The pilot results assisted in determining the validity which is the extent the instrument was measuring what it purports to measure, and the reliability which was concerned about the consistency of the measuring instruments.

\section{Data Collection procedures}

After receiving a letter of approval from the Graduate School, Kenyatta university, the researcher sought ethical clearance from the Ethics and Review Committee and used the two documents to get a research permit from the National Council for Science \& Technology, and Innovation (NACOSTI). The correct protocol was followed by firs obtaining permission from County Director of Education and the County Government of Homa-Bay before proceeding to collect data in the field. The researcher clarified all areas of the research instruments in order to optimize the response rate. After administering the instruments, the researcher waited for the respondents to fill in and then collected the filled in questionnaires immediately to a void a situation where the respondents shared responses.

\section{Data analysis}

Quantitative data generated from questionnaires were analyzed with the assistance of the Statistical Package for Social Sciences(SPSS) Computer software was used to compute both descriptive (means, standard deviation) and inferential statistics (correlations, simple and multiple regression) for the first phase of the mixed methods design. This was followed by the qualitative data analysis which was done manually using thematic and discourse analysis during the second phase. Triangulation was conducted to merge the data and form the final analytical platform for reporting the findings using a combination of tabulations, graphs and direct quotes to explain the findings (Orodho, Nzabalirwa, Odundo, Waweru \& Ndayambaje,2016)

\section{FINDINGS}

\section{Findings}

The head teachers and ECDE teachers were requested to indicate their views on recruitment of ECDE teachers and it's the influence on curriculum implementation. The study sought the views of head teachers and teachers on teacher recruitment and influence on curriculum implementation. They were asked to indicate their responses for various areas in relation to teachers' recruitment on the influence of curriculum implementation in a 5-point Likert scale with (1-strongly disagree, 2-Disagree, 3-Not sure, 4-Agree, 5-Strongly agree) as indicated in the Table 1.. The basis for interpretation was that any mean below 2.5 meant disapproval while above 2.5 meant approval.

Table 1: Head teachers' view on recruitment of teachers and the influence on curriculum implementation

\begin{tabular}{|c|c|c|c|c|c|c|}
\hline Item & 1 & 2 & 3 & 4 & 5 & Mean \\
\hline $\begin{array}{l}\text { New teachers are recruited and posted to } \\
\text { the centre immediately there exist a } \\
\text { vacancy }\end{array}$ & $\begin{array}{c}67 \\
(34.4 \%)\end{array}$ & $\begin{array}{c}57 \\
(29.2 \%)\end{array}$ & $\begin{array}{c}26 \\
(13.3 \%)\end{array}$ & $\begin{array}{c}30 \\
(15.4 \%)\end{array}$ & $\begin{array}{c}15 \\
(7.7 \%)\end{array}$ & 2.29 \\
\hline $\begin{array}{l}\text { The recruitment of teachers is advertised, } \\
\text { shortlisted and interviews done based on } \\
\text { merit. }\end{array}$ & $\begin{array}{c}35 \\
(17.9 \%)\end{array}$ & $\begin{array}{c}37 \\
(19.0 \%)\end{array}$ & $\begin{array}{c}29 \\
(14.9 \%)\end{array}$ & $\begin{array}{c}56 \\
(28.7 \%)\end{array}$ & $\begin{array}{c}38 \\
(19.5 \%)\end{array}$ & 3.13 \\
\hline $\begin{array}{l}\text { The recruitment of teachers is done in a } \\
\text { fair, transparent and professional manner. }\end{array}$ & $\begin{array}{c}50 \\
(25.6 \%)\end{array}$ & $\begin{array}{c}37 \\
(19.0 \%)\end{array}$ & $\begin{array}{c}38 \\
(19.5 \%)\end{array}$ & $\begin{array}{c}37 \\
(19.0 \%)\end{array}$ & $\begin{array}{c}33 \\
(16.9 \%)\end{array}$ & 2.82 \\
\hline $\begin{array}{l}\text { The Teacher / pupil ratio is appropriate for } \\
\text { pupil individual attention and pupils' } \\
\text { differences. }\end{array}$ & $\begin{array}{c}75 \\
(38.5 \%)\end{array}$ & $\begin{array}{c}50 \\
(25.6 \%)\end{array}$ & $\begin{array}{c}21 \\
(10.8 \%)\end{array}$ & $\begin{array}{c}29 \\
(14.9 \%)\end{array}$ & $\begin{array}{c}20 \\
(10.3 \%)\end{array}$ & 2.29 \\
\hline $\begin{array}{l}\text { There is a clear policy guiding teacher } \\
\text { recruitment process. }\end{array}$ & $\begin{array}{c}45 \\
(23.1 \%) \\
\end{array}$ & $\begin{array}{c}22 \\
(11.3 \%) \\
\end{array}$ & $\begin{array}{c}57 \\
(29.3 \%) \\
\end{array}$ & $\begin{array}{c}49 \\
(25.1 \%) \\
\end{array}$ & $\begin{array}{c}22 \\
(11.3 \%) \\
\end{array}$ & 2.90 \\
\hline
\end{tabular}

Note: 1-strongly disagree, 2-Disagree, 3-Not sure, 4-Agree, 5-Strongly agree Source: Researcher, 2021

Table 1 showed that $28.7 \%$ of head teachers agreed and $19.5 \%$ of head teachers strongly agreed that recruitment of teachers is advertised, shortlisted and interviews done based on merit while $36.9 \%$ disagreed. On the question about new teachers being recruited and posted to the centre immediately there exist a vacancy, $63.6 \%$ of the lead teachers disagreed while $23.1 \%$ agreed. On whether recruitment is done on a fair, transparent and professional manner, $44.6 \%$ of the head teachers agreed while $38.5 \%$ disagreed. On clear policy on recruitment, $34.4 \%$ of the head teachers agreed that there are clear policies on recruitment whereas $36.4 \%$ disagreed.

Using a scale of 1 - 5 (1-strongly disagree, 2-disagree, 3-not sure, 4-agree, 5-strongly agree), the mean response of 3.13 was obtained when the head teachers were requested to state their views on recruitment of 
teachers as far as advertisement, shortlisting and conducting of interviews is concerned. From the above mean, views were varied from the lead teachers on the recruitment process of teachers on advertisement, shortlisting and interviews being done based on merit. Nearly a half of the head teachers hold the view that advertisement, shortlisting and conducting interviews are based on merit. Slightly above a half of the head teachers had a contrary opinion.

The head teachers generally disagreed (mean response 2.29), that the new teachers were recruited and posted to the centres immediately there exist a vacancy and teacher / pupil ratio was appropriate for pupil individual attention and pupils' differences (mean response 2.29). Head teachers noted the county government had not recruited enough teachers. The teacher-pupil ratio was still relatively low and there was need to fill the gap. This finding concurs with the study by the UNESCO Institute for Statistics UNESCO, (2006) which indicated that Africa is facing a looming teacher's shortage in its effort to achieve Universal Basic Education and Education for All (EFA) by 2015. The report further noted that unless there is substantial investment on teacher recruitment, the Education for All dream will not succeed. This shortage of ECDE teachers certainly affects the implementation of ECDE curriculum.

The ECDE teachers were similarly presented with a questionnaire formulated a 5-point Likert scale statements (1-strongly disagree, 2-Disagree, 3-Not sure, 4-Agree, 5-Strongly agree) and teachers were required to respond to them. Their responses are as shown in the Table 2.

Table 2 : ECDE teachers' views on recruitment of teachers

\begin{tabular}{|c|c|c|c|c|c|c|}
\hline Item & 1 & 2 & 3 & 4 & 5 & Mean \\
\hline $\begin{array}{l}\text { New teachers are recruited and posted to } \\
\text { the center immediately there exist a } \\
\text { vacancy }\end{array}$ & $\begin{array}{l}91 \\
(32.9 \%)\end{array}$ & $\begin{array}{l}63 \\
(22.7 \%)\end{array}$ & $\begin{array}{l}44 \\
(15.9 \%)\end{array}$ & $\begin{array}{l}36 \\
(13.0 \%)\end{array}$ & $\begin{array}{l}43 \\
(15.5 \%)\end{array}$ & 2.54 \\
\hline $\begin{array}{l}\text { The recruitment of teachers is advertised, } \\
\text { shortlisted and interviews done based on } \\
\text { merit. }\end{array}$ & $\begin{array}{l}80 \\
(28.9 \%)\end{array}$ & $\begin{array}{l}38 \\
(13.7 \%)\end{array}$ & $\begin{array}{l}46 \\
(16.6 \%)\end{array}$ & $\begin{array}{l}65 \\
(23.5 \%)\end{array}$ & $\begin{array}{l}48 \\
(17.3 \%)\end{array}$ & 3.01 \\
\hline $\begin{array}{l}\text { The recruitment of teachers is done in a } \\
\text { fair, transparent and professional manner. }\end{array}$ & $\begin{array}{l}90 \\
(32.5 \%)\end{array}$ & $\begin{array}{l}36 \\
(13.0 \%)\end{array}$ & $\begin{array}{l}70 \\
(25.3 \%)\end{array}$ & $\begin{array}{l}43 \\
(15.5 \%)\end{array}$ & $\begin{array}{l}38 \\
(13.7 \%)\end{array}$ & 2.64 \\
\hline $\begin{array}{l}\text { The Teacher / pupil ratio is appropriate for } \\
\text { pupil individual attention and pupils' } \\
\text { differences. }\end{array}$ & $\begin{array}{l}99 \\
(35.7 \%)\end{array}$ & $\begin{array}{l}79 \\
(28.5 \%)\end{array}$ & $\begin{array}{l}39 \\
(14.1 \%)\end{array}$ & $\begin{array}{l}36 \\
(13.0 \%)\end{array}$ & $\begin{array}{l}24 \\
(8.7 \%)\end{array}$ & 2.27 \\
\hline $\begin{array}{l}\text { There is a clear policy guiding teacher } \\
\text { recruitment process. }\end{array}$ & $\begin{array}{l}81 \\
(29.2 \%)\end{array}$ & $\begin{array}{l}43 \\
(15.5 \%)\end{array}$ & $\begin{array}{l}74 \\
(26.7 \%)\end{array}$ & $\begin{array}{l}42 \\
(15.2 \%)\end{array}$ & $\begin{array}{l}37 \\
(13.4 \%)\end{array}$ & 2.85 \\
\hline
\end{tabular}

Note:1-strongly disagree,2-Disagree, 3-Not sure, 4-Agree, 5-Strongly agree Source: Researcher, 2021

Table 2 showed that $40.8 \%$ of the ECDE teachers reported that recruitment of teachers is advertised, shortlisted and interviews done based on merit while $42.6 \%$ of the ECDE teachers disagreed. On the question about new teachers being recruited and posted to the centre immediately there exists a vacancy, 55.6\% of the ECDE teachers disagreed while $28.5 \%$ agreed with the statement. On whether recruitment is done on a fair, transparent and professional manner, $45.5 \%$ of the ECDE teachers disagreed with the statement while $29.9 \%$ agreed. On clear policy on recruitment, $44.7 \%$ of the teachers disagreed whereas $28.6 \%$ of the teachers agreed. On qualitative data three head teacher reported that:

Recruitment of teachers in the county lacks transparency and fairness, to get recruited as an ECDE teacher, one has to know someone at the county, have a relative and or bribe the county education officials. They hardly follow the merit list for procedural fairness. The practice of lack of fairness and transparency was rampant in the entire county (HT,9,15,24).

Two practicing teachers also held nearly similar opinion, but added that:

Although the teachers are recruited using the merit list for procedural fairness, the number of teachers on the ground were inadequate and those in employment very overloaded with large size classes of 60 and above which is thrice the recommended number $(T 7 \& T 23)$

The views of two County Education Officers were that:

The county government policy on recruitment and deployment of teachers at this level is fairly transparent and provides an applicant with equal chance of selection and recruitment. The problem is lack of harmonization and delays in cash disburse as a result of bureaucracy form the national government. (CEO, $3 \& 7$ ).

\section{Hypothesis Testing on the influence of Teacher Recruitment on Curriculum Implementation}

To investigate whether there was any statistically significant influence of recruitment on early childhood development education curriculum implementation, the null hypothesis was tested. The hypothesis was stated as follows:

Multivariate regression analysis was utilized to examine the hypotheses in order to ascertain the nature of the 
influence between the independent and dependent variables of the study. To test hypothesis Ho , linear regression model was conducted.

The model was run as;

$\mathbf{Y}_{\mathbf{i}}=\boldsymbol{\beta}_{\mathbf{0}}+\boldsymbol{\beta}_{\mathbf{1}} \mathbf{X}_{1 \mathrm{i}}++\boldsymbol{\varepsilon}_{\mathbf{i}}$

Where:

$\mathrm{Y}_{\mathrm{i}}$ is Implementation of early Childhood Curriculum

$\beta_{0}$ is the constant term

$\beta 1$ is the beta coefficient of predictor variable X1 (Recruitment)

$\varepsilon_{\mathrm{i}}$ is error term assumed to be normally distributed with a mean of zero and constant variance as shown in Table 3.

Table 3 : Model Summary for Regression Analysis for Head Teachers Recruitment and Implementation of early Childhood Education Curriculum

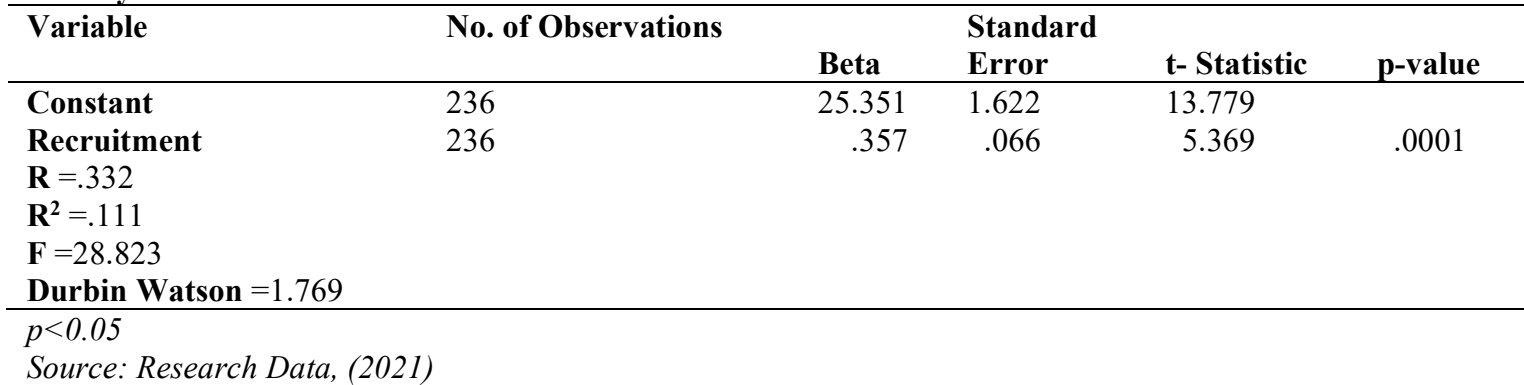

Table 3 indicates that the regression analysis of views of head teachers on recruitment of teachers and implementation of early childhood education curriculum, the value for Durbin-Watson $(D=1.769)$ is within the established range of 1-3 and consequently indicates that there was no autocorrelation in the sample. The correlation for the influence of lead teacher's recruitment and implementation of early childhood education curriculum was positive and significant $(p=.001, p<0.05)$. This means that there was a significant correlation between influence of recruitment of lead teachers and implementation of early childhood education curriculum in Homabay County. This implies that that whenever schools in the county invested on recruitment of lead teachers there was a significant improvement in their implementation of early childhood education curriculum. The $\mathrm{R}^{2}$ value of .111 implies that recruitment explains 11.1 percent of the variation in curriculum implementation while the rest 88.9 percent is attributed to other variables not factored in the investigation. These factors include the enrollment and class-size policy and its implementation on the ground, quality of curriculum implementation in terms of learner-teacher contact hours and the appropriateness of learning resources.

Table 4. show the model summary of regression analysis for the ECDE teacher's recruitment and implementation of ECDE curriculum

\begin{tabular}{llllrl}
\hline Variable & No. of Observations & Beta & $\begin{array}{l}\text { Standard } \\
\text { Error }\end{array}$ & t- Statistic & p-value \\
\hline Constant & 313 & 30.991 & 1.220 & 25.408 & \\
Recruitment & 313 & -.066 & .088 & -.746 & .456
\end{tabular}

$\mathbf{R}=\mathbf{. 0 4 2}$

$\mathbf{R}^{2}=.002$

$\mathbf{F}=.557$

Durbin Watson $=\mathbf{2 . 4 3 1}$

$\mathbf{p}<\mathbf{0 . 0 5}$

Source: Research Data, (2021)

Table 4 presents a model summary of the regression analysis of recruitment of ECDE teachers and implementation of early childhood education curriculum. The value for Durbin-Watson $(D=2.431)$ is also within the established range of 1-3 and indicating the absence of autocorrelation in the sample. The correlation for the influence of ECDE teacher's recruitment on implementation of early childhood education curriculum was positive but insignificant $(\mathrm{r}=.456, \mathrm{p}>0.05)$. This means that there was an insignificant influence of recruitment of ECDE teachers on implementation of early childhood education curriculum in HomaBay County.

This result implies that that whenever schools in in the County invested on recruitment of ECDE teachers there was no significant improvement in their implementation of early childhood education curriculum. This is contrary to the expectation during the current competency based curriculum (CBC) that apart from implementing the curriculum, classroom teachers should administer assessment to inform not only learning progress but also assess readiness for transition to primary school, and advise on required intervention and appropriate placement, especially for children with special needs as well as talented and gifted. . This result therefore sounds an early warning signal that ECDE teachers recruited at county levels in the country should be accorded the recognition 
they need to nurture talent of learners at this embryonic stage of academic development. This also automatically means that the recruitment policy vested to county governments may be introducing inefficiency mechanisms since their operations are not appropriately harmonized by the national government. The overall result is that inadequate and poorly supported teachers will not attain the envisaged goal of ensuring boys and girls at this level of education are adequately prepared for seamless transition to primary school and other higher levels of education.

\section{CONCLUSION AND RECOMMENDATIONS}

The study concluded that due to contradictory results from the head teachers and ECDE teachers regarding the recruitment and adherence to policy guidelines, the true position on the ground is that the county government is making spirited efforts to recruit teachers strictly following the guidelines. The problem was that the teachers on the ground were inadequate and overloaded since they handled over-enrolled classes with limited physical and infrastructural catalyze and influence effective curriculum implementation.

It is therefore imperative that the county government of Homa Bay does not employ enough ECDE teachers despite the availability of such teachers not employed. Therefore, the understaffing occasioned by insufficient recruitment of ECDE teachers by the county government of Homa Bay negatively influence implementation of early childhood education curriculum. A related finding is that the county government has not put in place a clear policy on provision of enablers to the teachers. It is imperative that each county government is having its own yardstick without any synchronization with the national government.

This paper therefore concludes that county government as is the case with Homabay County are not strategically nurturing the learners with appropriate, knowledge, skills and attitudes in the context of the prevailing teacher shortages and absence of provision of enablers of curriculum implementation. This quest for quality education is in tandem with the SDG-Goal 4 which promises that by 2030, ensure that all boys and girls have access to quality early childhood development and pre-primary education so that they are ready for primary education (Republic of Kenya,2020).

\section{Recommendations}

1. The County Government of HomaBay to consider recruiting more teachers and equitably distribute the in the various centers. This recommendation is based on the fact that currently there is a serious shortage of ECDE teachers in the county which has a negative influence on curriculum implementation.

2. The County Government of Homa Bay county should come up with a policy document on recruitment and schemes of service for the ECDE teachers in the county.

3. The national government should harmonize the operations of the 47 county governments not only in terms of teacher recruitment but also the enablers of effective curriculum implementation.

\section{References}

Akala, J, \& Maithya, P.M (2014). Effects of teacher recruitment and utilization policy on quality of Secondary School Education in Kenya. Journal of Research \& Met hod in education and social sciences.

Chepkewsis, R. B (2015). Factors influencing Pre-School teachers: Classroom performance in ECDE Centres in public schools in Kwanza Sub County. Unpublished Masters in Education Thesis, Moi University.

Creswell, J.W (2018).Educational research; Planning, conducting and evaluating qualitative and quantitative research ( $4^{\text {th }}$ Edition) : Thousand Oaks, C.A Sage.

Maithya, P. M., \& Akala, W. J. (2014). Effects of teacher recruitment and utilization policy on quality of secondary school education in Kenya. IOSR Journal of Research \& Method in Education (IOSR-JRME), 4(3), 10-17.

Martin, N.K, Schafer, N.J., Mclowry, S., Emmer, E.T \& Schaffer N.J.(2016). Expanding the definition of class management: Recurring themes and new conceptualizations. Journal of Classroom interaction 51(10 ,available at http://www.jstor.com

Mugenda, O. M., \& Mugenda, A. G. (2003). Research methods: Quantitative and qualitative approaches. Acts press.

Oliech, V.A, Ajowi J., Raburu, P (2017). Effects of staffing policies on public secondary school teachers' distribution in Homa-Bay County, Kenya. PhD Thesis. Jaramogi Oginga Odinga University of Science and Technology.

Orodho, J. A. (2009). Elements of education and social science research methods. Kanezja, Nairobi, 2(6), 26133.

Orodho J.,. A. (2017). Techniques of writing research proposals and reports in education and social sciences, Kanezja, Nairobi.

Owala, Z. M. (2016). Motivational factors influencing teacher job performance in pre-school in Rachuonyo North Homa-Bay County Kenya. International Journal of Innovative Research and Development, 5(5), 
121-132. Republic of Kenya. (2005). Sessional Paper No 1 of 2005 and Research. Government Printer.

Republic of Kenya. (2006). Early childhood development service standard guidelines or Kenya. Government Printer.

Republic of Kenya. (2012). A policy Education act; aligning education and training to the constitution of Kenya (2010) and Kenya Vision 2030 and beyond Government Press Nairobi Kenya.

Republic of Kenya. (2013). Teachers Service Commission Act, No. 20 of 2012.

Republic of Kenya. (2015). Education for All [National Review Report Nairobi Kenya].

Reynolds, A. J. (2000). Success in early intervention: The Chicago child parent centers. U of Nebraska Press.

Republic of Kenya (2020).). Taskforce Report on Enhancing Access, Relevance, Transition, Equity and Quality for Effective Curriculum Reforms Implementation. Ministry of Education, December 2020.

UNESCO. (2001). Education for all knowledge sharing-grassroots Stories-Kenya.

UNESCO. (2012). Expanding equitable early childhood education is an urgent need policy Paper, 03 Paris France: UNESCO.

UNESCO. (2015). EFA global monitoring paper 2015; Achievements and challenges: Paris France: UNESCO. 